\title{
Public Policy: Inconsistency of Online and Conventional Land Transportation Regulations in Indonesia on Social Conflict Implications
}

\author{
Djasa Pinara Gusti ${ }^{1, *}$, Bambang Supriyono², Hendro Wardhono ${ }^{3}$, Mochammad Rozikin ${ }^{4}$ \\ and Bambang Slamet Riyadi ${ }^{5}$
}

${ }^{1}$ Doctor Program of Public Administration, Faculty of Administrative Sciences, Universitas Brawijaya, Malang, East Java, Indonesia

${ }^{2}$ Promoter, Professor, Faculty of Administrative Sciences, Universitas Brawijaya, Malang, East Java, Indonesia

${ }^{3}$ Copromotor, Lecturer at the Faculty of Administrative Sciences, Universitas Dr. Soetomo. Surabaya. East Java. Indonesia

${ }^{4}$ Copromotor, Associate Professor for Faculty of Administrative Sciences Universitas Brawijaya, Malang City. East Java, Indonesia

${ }^{5}$ Associate Professor for Faculty of Business Law Universitas Nasional, Jakarta, Indonesia

\begin{abstract}
This scientific journal research analyzes a public policy on regulatory inconsistencies made by public officials that cause social conflict in society. The research problem focuses on PM 12/2019 regulations with UULLAJ/2009. The research approach method was qualitative. Creswell defines the qualitative method as a research method based on a constructive perspective, that is various meanings; meanings that are constructed socially and historically to develop a theory or pattern. The researchers collected and developed open data, intending to develop themes from the data obtained. This research aims to describe in depth the facts related to the inconsistency of regulations made by public officials which have an impact on the conflicts between the riders of online-based motorcycle taxi and conventional motorcycle taxi as land transportation in Indonesia. The data collection technique used document study. The observations carried out were passive participatory observations because the researchers only visited the research location and observed any events that occurred related to the conflict between online GOJEK riders and conventional OJEK riders in the research site. The research used interactive data analysis technique. Activities in data analysis consisted of: (1) data reduction; (2) data presentation; and (3) conclusion/verification. Based on the research data, it could be concluded that there were inconsistencies of public policy regulations regarding motorcycles (two-wheeled vehicles), as online-based public transportation vehicles based on PM 12/2019 with UULLAJ/2009, Article 47. In this case, motorcycles are not included in the category of public transportation types. The immediate solution should be made based on the results of research on online-based land transportation to date in Indonesia, since it has not been regulated by regulations on public transportation. Moreover, the technology platform service providers can no longer deny that their services are actually public transportation services. Online-based land transportation must also be regulated in the form of laws and regulations on public transportation and under the law on road traffic and transportation. This indicates that Law Number 22 of 2009 on Road Traffic and Transportation needs to be revised, and at the same time provides a legal protection for the regulations related to online-based land transportation.
\end{abstract}

Keywords: Public policy, regulation, transportation, social conflict.

\section{INTRODUCTION}

\subsection{Research Background}

This scientific journal research analyzes a government policy by the Ministry of Transportation of the Republic of Indonesia as a public official who has made a regulation on the online motorcycle transportation model (TSMO) as regulated in the Minister of Transportation Regulation of the Republic of Indonesia Number PM 12 of 2019 on Protection and Safety of Users of Motorcycle Used for Public Interest

*Address correspondence to this author at the Doctor Program of Public Administration. Faculty of Administrative Sciences, Brawijaya University, Malang, East Java, Indonesia; Tel: +6231-553737; Fax: +6231-556703;

E-mail: pdia.fia@ub.ac.id

cc. E-mail: bambang.riyadi@citivitas.unas.ac.id
(PM 12/2019). The regulation is inconsistent with conventional regulations based on Law of the Republic of Indonesia Number 22 of 2009 on Road Traffic and Transportation (UULLAJ). In addition, this regulation does not have a legal protection in the form of statutory regulations on it. At the implementation level, it creates conflicts with conventional motorcycle taxi riders (TSMK), (the Minister of Transportation Regulation of the Republic of Indonesia Number PM 12 of 2019 on Protection and Safety of Users of Motorcycle)

The preamble of point 2 of the Regulation of the Minister of Transportation of the Republic of Indonesia Number PM 12 of 2019 on Protection and Safety of Users of Motorcycle Used for Public Interest (PM 12/2019) is based on Law Number 22 of 2009 on Road 
Traffic and Transportation (UULLAJ/2009). But in PM $12 / 2019$, there are several inconsistent articles with several articles of UULLAJ/2009. (Law Number 22 of 2009 on Road Traffic and Transportation)

The inconsistency of PM 12/2019 is shown in article 3 paragraph (2) in which the motorcycles used for the benefit of the community as referred to in paragraph (1) must fulfill the following aspects: a. safety; b. security; c. comfort; d. affordability; and e. regularity. Article 7 paragraph (1) states that the fulfillment of affordability aspect as referred to in Article 3 paragraph (2) letter $d$ must at least fulfill the following conditions: a. The rider provides services to the Passenger to the destination point according to the agreement between the Rider and Passenger; and $b$. The rider charges a service fee according to the agreement between the Rider and Passenger. Meanwhile, UULLAJ/2009, Article 47 paragraph (2) states that motor vehicles as referred to in paragraph (1) letter a are categorized by the following type: a. motorcycle; b. passenger car; c. bus; d. freight wagon; and e. special vehicle. Article 47 paragraph (3) on Motor Vehicles as referred to in Article 47 paragraph (2) letter b, letter $c$, and letter $d$ categorized the motor vehicles by function as follows: a. Individual motor vehicles; and b. Public motor vehicles. In this case, motorcycles are not included in the category of public transportation types. (Law Number 22 of 2009 on Road Traffic and Transportation)

Inconsistencies in policy regulations are shown here, such as in the definition of motorcycle, in PM 12/2019, Article 1 point 1 which states; motor vehicle is any vehicle that is driven by mechanical equipment in the form of a machine other than a vehicle running on rails. In other hand, Article 1 point 7 states that motorcycles are two-wheeled motor vehicles with or without houses and with or without side carriages or three-wheeled motor vehicles without houses. Article 1 point 8 states that houses are parts of motorcycle located on the ground in the form of cargo spaces, both for people and goods. Meanwhile, the definition of a motorcycle in UULLAJ in Article 1 point 20 states, a motorcycle is a two-wheeled motor vehicle with or without houses and with or without side-trains or three- wheeled motor vehicles without houses.

Moreover, the inconsistency of PM 12/2019 regulation as regulated in Article 1 point 2 is also shown as follows; electronic system organizer is any person, state administrator, business entity, and community who provides, manages, and/or operates Electronic Systems individually or jointly, for users of electronic systems, for their own needs, and/or for the needs of other parties. Article 1 point 3 states; application company is an electronic system provider that provides technology-based applications in the field of land transportation. Article 1 point 4 states; motorcycle users are motorcycle taxi riders and passengers. Based on the article in the PM 12/2019 regulation that is not contained in UULLJ, it can be said that the regulation made by the Ministry of Transportation is considered invalid.

The inconsistency of PM 12/2019 regulation was also responded by one of the members of the People's Representative Council of the Republic of Indonesia who did not recognize online motorcycles as public transportation, and showed that based on data on the use of two-wheeled motor vehicles, the tendency was that there were more than $70 \%$ of accident victims (Siregar Efrem, 2019). Discourse on the cancellation of PM 12/2019 and the involvement of People's Representative Council would amend Law Number 22 of 2009 on Road Traffic and Transportation. This was conveyed by the Deputy Chairperson of Commission V of the People's Representative Council of the Republic of Indonesia, Mrs. Nurhayati Monoarfa who said that the revision of transportation regulations was still under discussion on academic notes. However, most members of Commission $V$ agree with the idea. Most factions agree that two-wheeled vehicles should not be used as transportation in general. This decision is made by considering the safety factor. Nurhayati said that only two-wheeled vehicles such as motorcycles that were legalized as public transportation. She continued that based on data from the Indonesian Police Traffic Corps, $73 \%$ of road traffic accidents involved motorcycles. However, the statement is inconsistent, as Nurhayati said that motorcycles were not recognized as a means of public transportation, but online motorcycle taxi riders would not be disturbed because motorcycles could be used as a means of delivering goods or logistics. It was not public transportation for people, but for food and goods. Nurhayati states that public transportation should prioritize security, comfort and safety. Therefore, motorcycles are not supposed to be public transportation. Nurhayati emphasizes that the government, both central and regional, has a mandate to provide public transportation and hopes that with this public policy, the government, in this case is the Ministry of Transportation, will focus again on providing proper public transportation (Monoarfa, 2020). 
At the implementation level, the progress of TSMO services has two sides. One side offers convenience and affordability, while on the other hand, the presence of TSMO is also prone to trigger social conflicts. The conflict that marks the conflict between TSMO and TSMK (conventional motorcycle transportation) has led to acts of violence such as blocking roads along with insults and forced raids done unilaterally, causing physical violence (Prihatin, 2017; 9). Changing the model from TSMK to TSMO is very attractive to people in urban areas and this is a form of social change that requires ease of use of transportation modes. Changes that occur in society are normal symptoms. Its influence can spread rapidly to other parts of the world in modern communication (Soekanto; 2009; 259). The TSMO model is the advancement of technology and society in urban areas. The shift of TSMK user services to TSMO is influenced by the advancement of communication tools and the desire of the Indonesian people who always want convenience. Community behavior in responding to social change will be accepted if the changes provide benefits as an increase in living standards, not against the legal norms prevailing in society. This transition triggers conflicts between TSMK riders such as angkot (share taxi), taxi, bentor (becak motor), and conventional motorcycle taxi riders and TSMO riders because the turnover of the first decreases due as they are unable to compete with the second.

Social conflicts due to inconsistencies in regulations made by public officials in the form of tensions between TSMK and TSMO riders were started at the end of 2015. The first recorded case was the incident on October 3, 2015, where a clash between the riders of online motorcycle taxi and conventional motorcycle taxi at the University of Indonesia (UI) campus, Depok. The incident was started when the online motorcycle taxi rider was suddenly beaten by someone who was believed to be a conventional motorcycle taxi rider after dropping off passengers at $\mathrm{UI}$ campus. Responding to this incident, a number of the victim's colleagues then carried out a sweeping action in UI conventional motorcycle taxi. The conflict continued and extended to other cities in Indonesia. Recently in South Tangerang, an online motorcycle taxi rider was hit by a blue share taxi driver around Tangcity Mall. The incident coincided with a demonstration marked by a sweeping action by a Tangerang city transportation driver regarding the existence of online transportation. For this incident, the online motorcycle taxi riders took retaliation. They convoyed on several Tangerang roads and damaged several share taxis (Prihatin, 2017;10).
The continuation of the conflict of PM 12/2019 inconsistency during the Covid 19 pandemic, and confusions whether it is allowed or not for TSMO to transport passengers during the implementation of large-scale social restrictions (PSBB) was confusing the public and increasing the risk of spreading Covid19.This refers to the overlapping regulations of the Minister of Transportation of the Republic Indonesia Number PM 18 of 2020 with Regulation of the Minister of Health of the Republic of Indonesia Number 9 of 2020. Statements of online motorcycle taxi riders (gojek) who are looking for money but must ignore risks, are also confused. In making the regulations, the government must be aligned, by determining one exact definition. If there are differences like this, it seems that the government is less firm. This confusion arises since TSMO has been carrying passengers during the implementation of Large-Scale Social Restrictions (PSBB) in Jakarta (Setijowarno Djoko (2020). The Governor of the Special Capital Region of Jakarta, Anies Baswedan, also emphasizes that TSMO is not allowed to carry passengers during the PSBB period. It referred to the Regulation of Minister of Health Number 9 of 2020 on Large-Scale Social Restrictions (PSBB) which was set on April 3 2020. Anies conveyed this matter after the issuance of the Regulation of Minister of Transportation number 18 of 2020 which was passed six days ago, and one of its verses allowed TSMO to transport passengers (Baswedan Anies, 2020).

Another inconsistency of the TSMO regulations is also carried out by the Acting Minister of Transportation Luhut Binsar Pandjaitan who issued a Regulation of Minister of Transportation Number 18 of 2020, where article 11 paragraph $1 \mathrm{C}$ states that TSMO is limited to its use only for the transportation of goods, while in paragraph 1D it states that TSMO can carry passengers. This verse contradicts the PSBB guidelines stipulated in the Regulation of Minister of Health No. 9/2020 (Luhut Binsar Pandjaitan, 2020). Police Traffic Director of the Republic of Indonesia, Metro Jakarta Raya, Police Commissioner Sambodo Purnomo Yogo, said that now his party would follow the Regulation of Minister of Transportation issued by the Acting Minister of Transportation Luhut Binsar Pandjaitan, allowing TSMO to transport passengers. Yogo will refer to what has been conveyed by a spokesman for the Ministry of Transportation who said that TSMO could carry passengers. (Sambodo Purnomo Yogo, 2020). Based on several regulatory conflict problems that are applied during the Covid 19 
pandemic by several public officials above, there has been an overlapping in article one with another article in the Regulation of Minister of Transportation. In article 11 paragraph $1 \mathrm{C}$ and 1D, there is dualism, as interpreted by several media. The Ministry of Transportation said that TSMO can carry passengers, but in the Regulation of the Ministry of Transportation in Article 11 it is also clear that TSMO is only allowed to carry goods. (Yuniar Woro Resty, 2020).

Based on the background of the above problems, it can be said that the Ministry of Transportation of the Republic of Indonesia has used excessive discretion as a public official to issue several regulations on online motorcycle transportation without having a legal basis, so that it can be called as the abuse of power and authority.

In this case, the abuse of power and incompetence are the main parameters of whether or not there are deviations in the use of government authority, apart from other administrative law principles. If there is an element of abuse of authority and arbitrariness, then there is an element of maladministration, and of course there is an element of an act against the law, and the act becomes the personal responsibility of the official who commits it. Abuse of power has a broader meaning than infeasibility, but in the study of administrative regulations (Riyadi et al., 2020: IJCS: 9: 1294). So, it implies social conflict. The conflict of interest between public duties and private interests has created many scandals involving public officials with very serious consequences. (Riyadi et al., 2020: IJCS: 9:1293).

\subsection{Research Originality}

In line with Dyah Mutiarin, et al. as the researchers in a scientific journal entitled "How government regulations and policies respond to the growing onlineenabled transportation service (OETS) in Indonesia, Philippines, and Taiwan?", this scientific journal aims to explore the dynamic context of the sharing economy in the transportation sector. This paper looks at the development of government regulations on the growth of transportation network company businesses in Indonesia, Philippines (represented as a middleincome country) and Taiwan (a high-income country). How do government regulations and policies respond to the developing online transportation services (OETS) in Indonesia, Philippines and Taiwan? (Dyah Mutiarin, et al. Achmad Nurmandi, Hazel Jovita, Mukti Fajar and Yao- Nan Lien 2019)
Design/methodology/approach - This was a qualitative comparative study. Data on the transportation sector of each country had been collected from leading online sources. Findings - This study found evidence that the policy responses made by the Governments of Indonesia, Philippines and Taiwan to the shared economy in the transportation sector were incremental and trial-error based. Limitation of research - This paper does not address the relationship of policy issues between riders and platform companies. Practical implications - The future of the relationship between sharing companies and local government suggests that the focus should be on stronger consumer protection, deeper economic redistribution, and the achievement of other policy objectives. Originality/value - This was a comparative study of different levels of economy, especially between low or middle income countries and high income countries. (Mutiarin et al.; 2019). The similarity in this study is the regulatory policy in the transportation sector, the difference with this research is that the research of Dya Mutiarin et al., discusses the regulations of developing countries like Indonesia, Philippines and Taiwan regarding policies between riders and companies. While this research discusses the inconsistency of the regulations of the Ministry of Transportation regarding online-based motorcycle transportation made by public officials with the social conflict implications.

Other researchers, Jihane El Ouadi, Nicolas Malhene, Siham Benhadou and Hicham Medromi, in a scientific journal entitled "Strategic Zoning Approach for Urban Areas: Towards a Shared Transportation System" investigate downstream transport demand as a prerequisite for achieving strategic implementation of the overall transportation system. Machine learning has recently been widely applied to support decision making at several levels of logistics operations: prediction of travel/arrival times, prediction of logistics space occupancy, route optimization, and so on. However, strategic decision making often ignores the estimates of current trends. By targeting this perspective, this paper aims to propose an urban zoning approach based on the estimated time series of supply chain demand through customer grouping. To take our approach, we have selected a set of machine learning algorithms that are considered robust according to the literature and benchmarks of accuracy achieved. Considering computational results based on real-life data, a number of analytical insights are illustrated (Ouadi et al., 2020: Procedia Computer 
Science: 170: 212). The similarity in this study is the regulatory policy in the transportation sector, the difference with this research is that Ouadi etal., discuss the regulations of Warsaw, Poland regarding regulatory policies with an improved approach to analyze machine algorithms, so that congestion does not occur. While this research discusses the inconsistency of regulations of the Ministry of Transportation of the Republic of Indonesia, regarding online-based motorcycle transportation made by public officials with social conflict implications.

Vanessa Stjernborg and Ola Mattisson, in a scientific journal entitled The Role of Public Transport in Society - A Case Study of General Policy Documents in Sweden, conduct as research on how local governments in Sweden view the role of public transport in society, and to investigate how public transport is used in a strategic capacity. By studying public policy documents, the aim is to gain a broader understanding of the role of public transport based on its social context. Documents from 15 regions and 27 cities were analyzed using qualitative content analysis. The results showed that public transportation was considered an important factor for achieving other goals and public values, especially those related to economic and environmental issues; and that the social dimension is not prioritized. Rail-related public transport is often recommended, as well as collaboration between organization and land use and integrated transport planning. However, the documents studied showed large overall differences in the way districts and cities dealt with public transport problems. It should be a priority in Sweden's main guide document to treat public transport consistently and give it the same priority as other public functions - not least because Sweden's treatment of public transport is a natural reflection of its entire society and can influence priorities and considerations in states and municipalities across the country. The similarity in this study is the regulatory policy in the transportation sector, the difference with this research is that Stjernborg et al., discuss transportation policy in Sweden, while this research discusses the inconsistencies of regulations of the Ministry of Transportation of the Republic of Indonesia regarding online-based motorcycle transportation made by public officials with social conflict implications. (Vanessa Stjernborg and Ola Mattisson, in a scientific journal entitled The Role of Public Transport in Society)

Based on the three previous studies, the originality of this study is shown. Besides, some countries do not implement online-based motorcycle transportation regulations, and it is only carried out in Indonesia even though there is no legal protection for the policies carried out by the Ministry of Transportation of the Republic of Indonesia.

The research problems, based on the background and previous research, of this study are first, to analyze the inconsistencies of online-based land transportation regulations based on PM 12/2019 with UULLAJ/2009 which have social conflict implications. Second, how the regulations of online-based motorcycle as land transportation operating without any social conflict?

\subsection{Significance of Research}

Theoretically, this research should be able to develop science in public policy in the formation of regulations, expand knowledge among academics, especially public policy students, develop the concept of public policy conflicts, as well as become a reference material for deepening and enriching scientific repertoire regarding regulatory inconsistencies.

For the Government, this research wishes to provide an input for the executive and legislative parties in making reforms in the field of online-based land transportation which is feasible, comfortable, safe and inexpensive for the community. This research can also be used as input for related institutions in reviewing any policies related to online-based land transportation. Last, this research is expected to be able to give birth to a caring attitude of the public in order to understand the inconsistencies in regulations made by public officials.

\section{RESEARCH METHODS}

This study used descriptive research method with qualitative approach. These methods and approaches were used because the research problem only described facts in depth regarding the inconsistencies of regulations made by public officials which had an impact on the conflict between online motorcycle taxi and conventional motorcycle taxi riders in Indonesia.

The data in this study were qualitative data in the form of words and the meaning behind the words. Data sources were the subjects from which data were obtained, which could be people, events or activities, places or locations, objects, various images or recordings, documents or archives. Data collection techniques used were observation, interviews and document study. The observation carried out was 
passive participatory observation, because the researcher only came to the research location and observed what events occurred related to the conflict between online motorcycle taxi riders and conventional motorcycle taxi riders in the research site.

Data validity in qualitative research is an attempt to increase the degree of trustworthiness of the data. In this study, the triangulation used was triangulation of data sources and triangulation of data collection techniques. Then the data analysis technique used was interactive data analysis techniques. Activities in data analysis consisted of: (1) data reduction; (2) data presentation; and (3) conclusion/verification.

\section{DISCUSSION AND ANALYSIS}

\subsection{Analysis of Public Policy on Online- Based Motorcycle Transportation Regulations in Indonesia}

One of early figure who tries to define public policy is Thomas Dye. Thomas Dye describes public policy as everything chosen by government to do or not to do something. The definition is deemed too narrow to describe the public policy. There are two meanings that can be taken from the Thomas Dye's definition. First, Dye argues that public policy can only be made by government, not private organizations. Second, Dye reaffirms that the government is the one who decided the public policy regarding whether something should be done or not (Riyadi, 2017, The Philosophy of Law Review: According to Pancasila Value; IJRD:07; 5; June; 1317). Public policy as social action of Government turns into action that has legal implications when public policy as a Government obligation is protected and regulated by legislation. James $\mathrm{E}$. Anderson classifies the types of public policy into: a. Substantive and Procedural Policies b. Distributive, Redistributive, and Regulatory Policies; and c. Public Goods and Private Goods Policies. (Riyadi, 2017; Sociology of law: An agrarian dispute settlement, International Journal of Law; 3; Issue 3; May; 54)

William Jenkins defines the public policy as a decision of various actors that are interconnected to achieve a certain goals. The matter needs to be underlined as William emphasis more on the public policy in the policy-making process, unlike Thomas Dye that only defines public policy as a choice made by the government. In addition, James Anderson defines public policy as the policy established by agencies and government officials, although these policies can be influenced by actors and outside factors. In making the policy, the government is required to make choice between objectives and alternatives, and the choice always involves the will. The government policy generally does not stand alone, but it consists of a coordinated set of policies to achieve a goal. (Riyadi, 2017, The Philosophy of Law Review: According to Pancasila Value; IJRD:07; 5; June; 1316)

Easton provides definition of public policy as an authoritative allocation of values for the whole society. Laswell and Kaplan also define it as a projected program of goals, values, and practices. Pressman and Widavsky as quoted by Budi Winarno define public policy as hypothesis containing preliminary conditions and predictable effects. Wolls as quoted by Tangkilisan states that public policy is a number of government activities to solve problems in the society, either directly or through various institutions that affect people's lives. (Riyadi, 2017; Sociology of law: An agrarian dispute settlement, International Journal of Law; 3; Issue 3; May; 57)

The concept of policy politics becomes a reference on how a policy also involves some processes that underlie the policy itself. Unfortunately, the concept of policy politics is still not used as a unified concept that can explain how the policy-making process takes place from the perspective of political science or the political events behind it. However, these two different things can of course still be related to one another. Politics and policies are two things that cannot be separated. In every policy that is made, it is built on the elements that influence it, whether it is political actors or political process, to the interests that cover it. Therefore, it can be concluded that a policy must be accompanied by a process behind it. This process is what is then attached to politics. Furthermore, Thomas P. Jenkin, as quoted by Miriam Budiardjo and Landman in Raffiudin, distinguishes two kinds of political theories into valuational theories and empirical theories, although the differences between the two groups of theories are not absolute. As mentioned above, valuational theories are based on how the values or norms are contained in political theory. At least, this kind of theory can certainly be linked to the actions or behavior of these political actors. Meanwhile, empirical theory explains more about the causes and effects that occur in the political process and political system. Basically, the empirical process is a process that goes through the senses so that things are different from the previous type which relates to an existing value or in other words, this type is value free (Rofiqi, 2020, Journal:26-27) 
Matters relating to policy politics in the policy itself will certainly not be far from the issue of value in the political science theory. From the point of view of good and bad values, it will certainly influence every decision making regarding a policy. On the other hand, things that are empirical can also be a deepening history related to things that have happened previously. In this case, the decision-making process in making a policy certainly considers the causal aspects, especially with the things that have been passed before. The two things mentioned above show how flexible the political theory is in the policy-making process. In contrast to William Dunn's political theory, he explains a policy theory which according to him is written rules which are formal organizational decisions, binding, and regulating behavior with the aim of creating new values in society. The policy will be the main reference for members of the organization or society in behaving. Dunn attaches a behavior to this understanding. In this case, policy will become the center of an organization because there are decisions related to rules which of course will be followed by each member and the behavior of the organization itself. Furthermore, Dunn also adds that policies in general can be both problem solving and proactive in nature. As previously discussed, the unity between policy and politics can also be suspected as a solver of a particular problem. Policy in this case will certainly be binding in which the rules become the output of a political process. (Rofiqi, 2020, Journal: 28)

Generally, political policy theory is a theory that has goals to be achieved. As Nofsinger points out, the political policy theory implies that if one party has economic policies that are superior to the other, then this party's period of government should lead to better economic performance. Nofsinger's theory certainly leads to economic policy as a reference, including the political process that influences it. Therefore, the unification between policy and politics will certainly lead to several things that are more substantive than the process itself (Rofiqi, 2020, Journal:28). The politics of public policy on transportation through the regulation of Law Number 22 of 2009 on Road Traffic and Transportation, which has a strategic role in national development and integration as part of the effort to advance the public welfare supports mandated by the 1945 Constitution of the Republic of Indonesia, and as part of the national transportation system, road traffic and transportation have their potential and role to be developed to achieve security, welfare, the order or road traffic and transportation in the framework of supporting economic development and the development of science and technology, regional autonomy and accountability for state administration.

Public policy towards land transportation is as what the government states and does or does not do. The policy can be in the form of goals or objectives of government programs in the field of transportation. From the above definition, it can be seen that in defining public policies the keywords are goals, values and practices. Public policy in this theory considers that it always has a goal, such as the policy that the government will provide in reducing traffic congestion (Ariesandi, 2020; Journal; 79). The determination of public policy is manifested in the form of laws and regulations made by the government. It is related to the regulation of road traffic and transportation, the division of authority between government agencies and local governments, regulation of matters of a technical nature of road traffic and transportation operations, road traffic and transportation infrastructure, and efforts to develop, prevent, regulate and enforce law. In the Law on road traffic and transportation (LLAJ), there are three objectives for implementing Road Traffic and Transportation, which are: a. the realization of Traffic and Road Transportation services that are safe, secure, orderly, smooth, and integrated with other modes of transportation to encourage the national economy, promote public welfare, strengthen national unity and integrity, and be able to uphold national dignity; b. ethics for the realization of national traffic and culture; and $c$. the realization of law enforcement and legal certainty for the community. (Article 3 of Law Number 22 of 2009 on Road Traffic and Transportation)

The politics of policy in the European continent have felt the existence of online- based transportation. This online transportation includes Transportation Network Companies (TNC) from the United States with online type of shuttle service, namely online car/taxi. TNC is defined as a company that provides transportation services by using an online application to connect passengers with these online transportation drivers. Regarding the sharing economy, it allows people to share equipment and services using the internet and Information and Communication Technology (ICT) applications. TNC in its application uses smartphones to connect passengers with free drivers not far from the passenger's place. The service provided by the driver will use their own private vehicle. Passengers can see the identity of the driver first along with the driver's rating as a reference before the service is provided. Passengers can also check the costs that will be 
incurred so that it is clear how much it will cost to use this service. After the passengers confirm the departure service, the TNC application will guide the driver to the passenger pick-up place. Then, when they arrive at the location, passengers can make bill payments. (Arbi, 2019: Jurnal: 318). The facilities used to run this business are not provided by TNC itself but rather the private property of the driver. TNC is a very innovative sharing economy business model today.

Another policy advantage related to Grab and GoJek (both are online service providers) transportation services is the various features provided by these two types of online transportation. Grab, for example, provides application features in the form of GrabBike (online motorcycle transportation service/online motorcycle taxi), Grab Car (black plate private car services rented to travel from one destination to another - point to point or hourly - at a flat rate per kilometers), Grab Taxi (a service that is focused as a meeting place for taxi service seekers and taxi meter networks) and Grab Express (an application-based express courier service that promises speed, certainty and security). For several big cities such as the capital city of Jakarta and its surroundings, the Grab application has been added to the Grab Food service (a food delivery service that has collaborated with several restaurants), Grab Hitch (bringing together drivers and passengers who have one-way travel routes and are divided into two types, namely Hitch. bike and Hitch car), Rental, and Grab Parcel (courier service with selectable delivery times according to consumer needs at a more economical price). Currently the Grab company is also adding the GrabFood feature to compete with its rival Go-Jek, which provides food delivery services (Go Food), however for the Makassar City area there are only 3 services, namely Grab Bike, GrabCar and GrabTaxi. (Anwar, 2017: Journal; 227).

\section{GO危JEK}
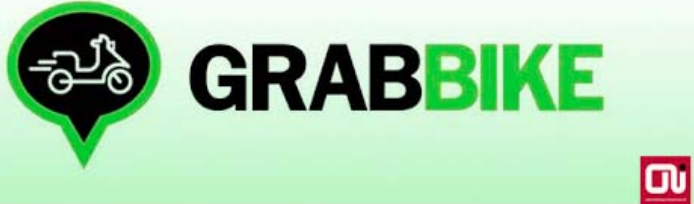

Figure 1: Transportation of online based GOJEK RIDE and GRAB BIKE for Passengers.
Public policy towards application-based transportation services began to bloom in 2014. At the beginning of its appearance, it was started by Uber application which carried Uber Taxi as a transportation service business based on an online application. Then, this was followed by the appearance of Go-Jek, Grab Bike, Grab Taxi, and other online-based applications. Online transportation company Go-Jek itself has been established since 2011 as a technology-based service provider that partnering with motorcycle taxi riders in several cities in Indonesia, such as in Jakarta, Bogor, Depok, Tangerang, Bekasi, Bandung, Bali and Surabaya. In early January $2015,200,000$ drivers were registered in the area, while 100,000 of them were in Jakarta area. The management and operational systems used combined modern startup technology. The success of Go-Jek can be seen from the number of Gojek application downloaders that have reached 5.5 million application downloader (Rofiqi, Journal, 2020;22).

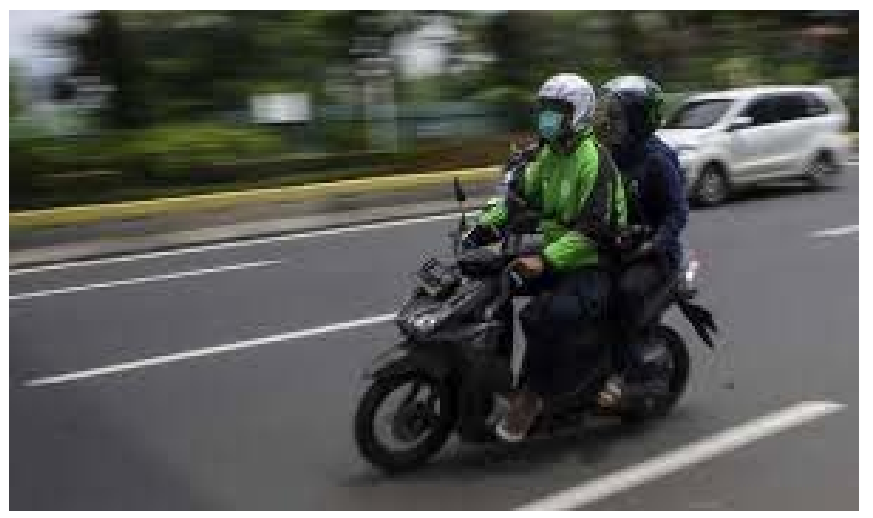

Figure 2: GOJEK, Online-Based Motorcycle Transportation Carrying Passengers.

Unlike Go-Jek's policies which originated from Indonesia, Grab is a transportation service application that is already popular in Southeast Asia, which until now has expanded to Singapore, Indonesia, Philippines, Malaysia, Thailand and Vietnam. Grab itself had been present in Indonesia since June 2012 as a taxi ordering application and since then it had provided various transportation options such as cars and motorcycles. In 2016, Grab company recorded tremendous business growth in Indonesia, after Grab rebranded itself in January 2016. The success of GoJek and GrabBike has also been a driving force for the emergence of other entrepreneurs to carry out similar businesses. As of 18 September 2015, there were 6 online motorcycle taxis ready to compete with Go-Jek, and Grab Bike including Smart Jek, Bang Jek, Jeger Taxi, Ojek, and Blue Jek. In this regard, even on March 
20, 2016, there were still many applications like Go-Jek and GrabBike, such as Smart Jek, Bang Jek, Jeger Taxi, Ojesy, Blue Jek, Uber, LadyJek, and My Blue Bird. In addition to the many business competition between online transportation services, to date, Go-Jek and GrabBike are the two services with most demand by the public, especially in Jakarta (Rofiqi, Journal, 2020; 23).

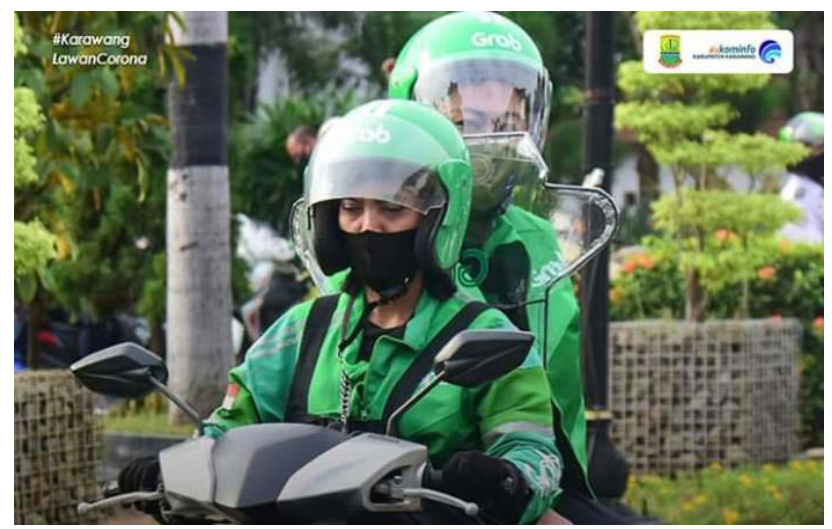

Figure 3: GRAB BIKE, Online-Based Motorcycle Transportation Carrying Passengers.

Go-Jek's idea emerged when Go-Jek's CEO, Nadiem Makarim, chatted with his regular motorcycle taxi drivers. It turns out that more than $70 \%$ of their work time is spent by waiting for customers. Nadiem Makarim immediately interviewed other motorcycle taxi drivers, and apparently all of them complained that it was difficult to find customers. Moreover, in Jakarta the congestion is getting worse. If there are transport and delivery services that are fast and practical, it will definitely help Jakarta residents. Go-Jek is a transportation company from Indonesia that serves the transportation of people and goods through motorcycle taxi services (Perdana, 2018, Thesis; 42).

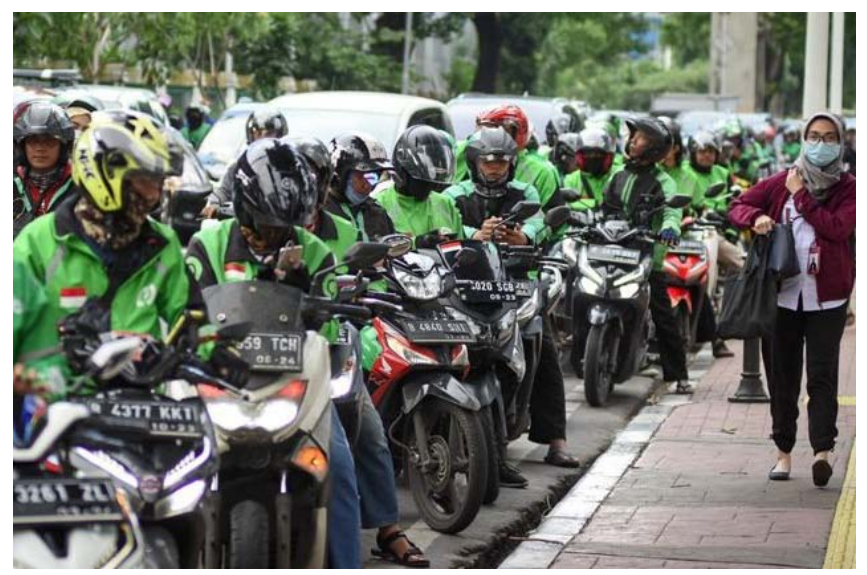

Figure 4: GOJEK RIDE \& GRAB BIKE, Online-Based Motorcycle Transportation Waiting for Passengers (do not have a terminal or base).
GO-JEK has officially operated in 25 major cities in Indonesia, including Medan, Batam, Palembang, Pekanbaru, Jambi, Padang, Bandar Lampung, Jabodetabek, Bandung, Sukabumi, Yogyakarta, Semarang, Solo, Surabaya, Gresik, Malang, Sidoarjo, Balikpapan, Samarinda, Pontianak, Banjarmasin, Manado, Makassar, Denpasar, and Mataram. The convenience for GO-JEK users is that Go-Jek can be ordered through the Go-Jek App which can be downloaded via the PlayStore or App store. In the first month this application has successfully reached 150 thousand downloads, with a rating of 4.4 out of 5 stars. There are 2 payment methods, namely cash and GoJek Credit (Go-Pay). Go-Jek Credit is a cashless payment method that can be used to pay for all services (Prime, 2018, Thesis; 44).

The company was founded in 2011 in Jakarta by Nadiem Makarim. Nadiem Makarim is known to have worked at Mckinsey \& Company, a well-known consultant in Jakarta and spent three years working there. It is also known that he worked as a Co-Founder and Managing Editor at Zalora Indonesia and then became Chief Innovation officer of my card. Armed with a lot of experience while working, Nadiem Makarim then ventured out of his job and founded Go-Jek company in 2011. GO-JEK's activities are based on three core values: speed, innovation and social impact. GO-JEK drivers and riders say that their income has increased since joining as partners, they also get medical and accident benefits, and have access to more customers through the app (Perdana, 2018, Thesis; 43).

Even though it resembles Grab as an online transportation service, in terms of service transportation policy, Go-Jek has a variety of features that show its uniqueness. In addition to motorcycle, car and courier transportation services, Go-Jek also adds Go-Food (delivery service which is No.1 food delivery service in Indonesia with more than 64,000 registered restaurants), GoMart (a service that allows consumers to shop for various types of goods from various stores), GoBox (large size moving services using a blind van), GoTix event information with access to purchase and delivery of tickets directly into the hands of consumers), GoGlam (beauty services without having to go to the salon), GoClean (professional cleaning services to the home or office), GoMassage (professional health massage services directly to the home), GoMed (an integrated service for purchasing medicines, vitamins, and other medical needs from licensed pharmacies), and GoCredit (credit top-up service directly from Go- 
Jek application). For the transaction system on Go-Jek application, consumers are faced with two choices that make it easier for them, namely GoPay and Grabpay (which are virtual wallet services for transactions in GoJek application) and direct payment system (cash). Grab and Go-Jek also provide loyalty programs where consumers can get tokens or bonuses every time they use the GoPay and GrabPay methods. In addition, GoJek provides a referral program that allows consumers to refer friends using GoPay and get rewards in the form of discount vouchers in several places that work with the two applications (Go-Jek Indonesia 2017).

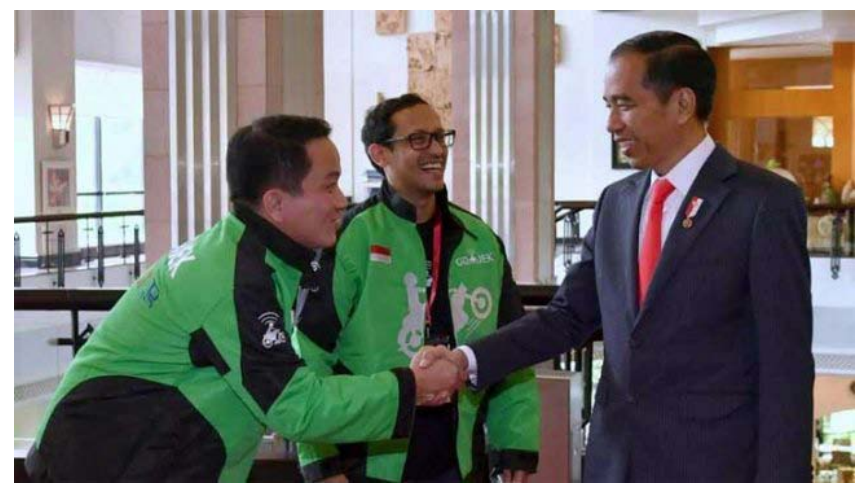

Figure 5: GOJEK as a food delivery. Photo of the President of the Republic of Indonesia, Joko Widodo together with the initiators of the GOJEK Indonesia company, Nadin Karim, and the GOJEK driver, ordering the President's Order for Chicken Satay.

Go-Jek transportation application also has added a new GoBusway service for DKI Jakarta area. GoBusway is a motorcycle taxi transportation service to take passengers to the desired Transjakarta bus stop. This service is also integrated with Go-Ride for ordering transportation to Transjakarta bus stop. With this latest service, consumers can find Transjakarta bus information for corridor 1, 2, 6, 8, 9, 10, 11, and 12 . However, for Makassar area, GoTix, GoLife (GoGlam, GoClean, and GoMessage) and Go-Busway applications until now are still not accessible to the public (Anwar, 2017: Journal; 228).

Based on the research data above, policy makers, in this case is the Minister of Transportation of the Republic of Indonesia, as an assistant to the President of the Republic of Indonesia, have used their discretion to make PM 12/2019, regarding legalization of onlinebased land transportation operations, although it is not a legal protection. In the interests of the wider community, in this case, the online-based two-wheeled motor vehicle transportation can run as a source of income and reduce unemployment. However, this public policy is inconsistent with UULLAJ/2009 regulations and does not have a legal protection in the form of a law.

Likewise, if the data from the research results are analyzed with public policy theory, it will be divided as follows; (i) an idea concerning a series of desired actions including a decision made not to take a particular step. (ii) actions taken by the government institutionally or by government officials must be accompanied by legal or customary sanctions that are acceptable to the parties because public officials often take actions outside of public policy, such as accepting bribes or acting beyond their authority;(iii) laws or regulations cannot be mistaken for the entire public policy; and the laws or regulations must not conflict with the objectives of public policy. In making PM $12 / 2019$ regulations, the policy makers must also consider the implementation, interpretation, enforcement, and impact of these laws and regulations, because all of them are part of public policy. Public policies can be issued by the central government to local governments with various types. Without this public policy, it is suspected that the online-based land transportation operation will not occur. Herein lies the relevance of public policy theory to this research problem.

\subsection{Conventional Land Transportation Policy (Based on UULLAJ /2009)}

Provisions regarding public transport operators must be carried out by a legal entity that has been confirmed in UULLAJ/2009 in Article 139 paragraph (4) which states: "The provision of public transport services is carried out by state-owned enterprises, local-owned enterprises, and/or other legal entities, in accordance with the provisions of laws and regulations". Further, UULLAJ LLAJ divides the types of public transportation using motor vehicles into 2 (two), namely: (1) transportation of people using public motor vehicles on routes, and (2) transportation of people using public motor vehicles not on routes. The UULAJ / 2009 also regulates the types of transportation for people using public motor vehicles in routes including: cross-border transportation, intercity transportation between provinces, intercity transportation within the province, urban transportation, and rural transportation. Meanwhile, the criteria for transportation of people using public motor vehicles in a route are: (1) having a fixed and regular route, (2) being scheduled.

At its implementation level, there has been land transportation using two wheels (bicycles without 
engines) in Indonesian society since a long time ago. However, it is wrong to assume that it has been the nature of Indonesian people to use motorcycles (two wheels) as a means of land transportation (motorcycle taxi). However, motorcycle taxi as land transportation is considered common, but the government, which is the Ministry of Transportation of the Republic of Indonesia, ignores the behavior of riders on the highway that have tendency to experience accidents.

Ojek or motorcycle taxi is a type of two-wheeled motor vehicle that operates as a transportation service that is included in the category of public transportation on a contract basis. This motorcycle taxi is basically owned by individuals or people who are active as motorcycle taxi riders, and usually they come from the lower to middle class. They are independent or not bound by deposits, regulations, and contracts with anyone. Basically, motorcycle taxi is the vehicle for the village or city community. The price for this motorcycle taxi is made by contract. There is an agreement between a motorcycle taxi rider and a passenger at the same time and place before the passenger uses the motorcycle taxi service. Therefore, the ability to negotiate here is crucial and it is common for this negotiation to take more times. The price made by negotiation means that the price of this motorcycle taxi service can be different at any time depending on the agreement between the motorcycle taxi rider himself and the passenger (Perdana, 2018: Thesis:47).

These motorcycle taxi riders also often ask for a really high a price for their services, and this is what makes motorcycle taxi users feel uncomfortable. Indeed, motorcycle taxis are relatively expensive when compared to other public transportation, because these motorcycle taxis are private/rental, which only transports one person at a time. Judging from its small shape, it can pass through various types of congestion and takes less time than other public transportation in Jakarta. Even though this motorcycle taxi is a favorite vehicle for use in congested city areas, the price of this service is what makes people think again about this service (Perdana, 2018: Thesis:48).

Based on the research data above as well as the analysis, the researcher argues that the government which is the Ministry of Transportation of the Republic of Indonesia as a public official has rationalized the deviation of Article 47 UULLAJ regulation policy which is very long. In this case, it can be said that the abuse of discretionary authority of public officials legalizes the motorcycle transportation (Ojek).
Regarding legal implications of abuse of power to the administration of public officials according to the opinion of Philipus M. Hadjon, administrative law is known as the term of authority, which is aligned with the term bevoegdheid. The difference between authority and the term bevoegdheid is that they are used both in the concept of public law and private law, whereas in Indonesia it is always used in the concept of public law that the use of authority is intended to control the behavior of legal subjects. Authority must have the legitimacy and conformity of the law, and contain interpretation of authority standards, which are general standards and special standards (Riyadi, 2020, Culture of Abuse of Power in Indonesia: IJCS; 9; 277).

\subsection{Public Policy Conflicts in Land Transportation Management in Indonesia}

Conflict is a necessity in every public policy. Public policy as a political instrument to allocate values needs to be treated in such a way by policy making actors. Bromell stated that public policy is essentially dealing with how to decide "who gets what and who pays given relative resource scarcity". But then the question arises about whose value belongs to and which value will be allocated by the policy making actor, or which public has its value contained in public policy. Until now, there are not many studies that pay attention to the centrality of conflict in public policy. The relationship of value allocation in public policy as one of the sources of conflict by examining the empirical substance of cases of public sector organizational structuring policies, in order to provide an understanding of the conflict and the central role of value in public policy practice which not only often focuses on the bureaucratic environment should be studied more (Apriani, 2019; $5 ; 1 ; 63$ ).

Ralf Dahrendorf's Conflict Theory became the basis for a study of the constitutionality of public policies on land transportation regulations for passengers using online-based motorcycles (GoRed) and land transportation for passengers using conventional motorcycles (OJEK). For him, social class grouping is No. longer based only on legal ownership of legality, but also on power relations. Here, there are three important concepts: power, interests, and social groups. In turn, the differentiation of interests that occurs might cause group conflict potential or of group actual conflicts that clash because they have antagonistic interests.

In Dahrendorf's view, it does not always mean that the owners act as controllers. He assumed that power 
relationships concerning subordinates and superiors to provide an element for the class birth. The groups clash will be the most easily analyzed as contradiction on the power relations legitimacy between ruling and lower-class groups (Riyadi, 2017; Sociology of law: An agrarian dispute settlement, International Journal of Law; 3; Issue3; May; 54).

The emergence of application-based transportation has raised pros and cons in society. In one hand, online transportation can be seen as a thing that provides convenience for drivers and consumers. On the other hand, online transportation has received a lot of criticism from conventional transportation drivers because it is considered as illegal transportation and seizes the livelihood of drivers of conventional transportation services. There are several problems that are often complained by conventional transportation drivers related to the operation of application-based transportation, namely operating permits, vehicle plate colors, places to pick up passengers, and fares (Anwar, 2017, Ethnographic Journal: 230-231).

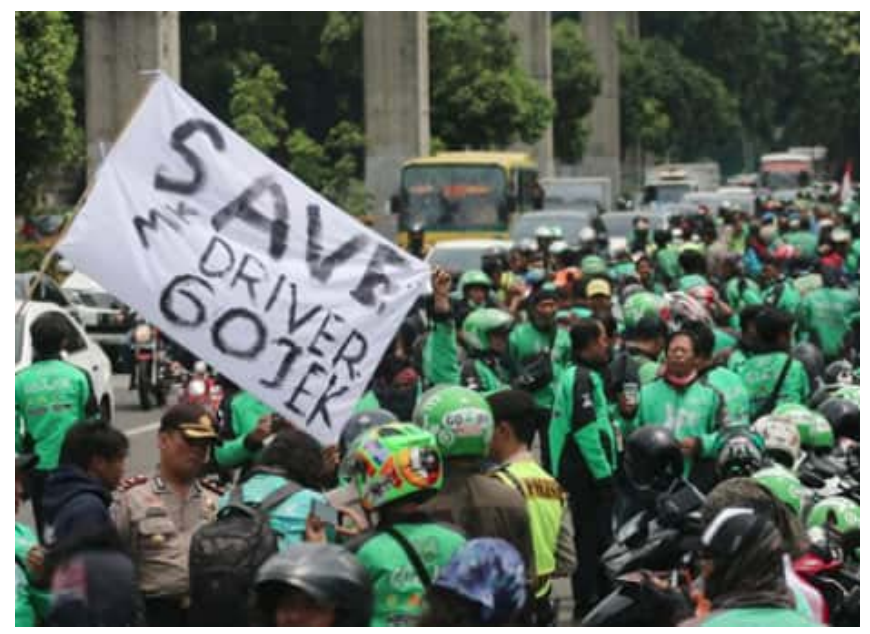

Figure 6: Conflict between GOJEK RIDER drivers and Conventional OJEK drivers.

The conflicts experienced by GOJEK drivers occur with conventional transportation drivers, fellow GOJEK drivers and GOJEK companies. The conflict with conventional transportation drivers occurs directly, either in the form of verbal conflict or physical violence. This conflict is caused by conventional transportation drivers who feel the impact of GOJEK, suffering a decrease in income. Conflict resolution efforts in the form of mediation by various parties have been made and resulted in rules for pick-up points or pick-up zones that are allowed for GO-JEK drivers. Conflicts among GOJEK drivers occur because of the disparity between the number of GOJEK drivers and the number of GOJEK consumers. As for the conflict with the GOJEK company in Kediri, it was due to the closeness or lack of information regarding the termination of partnerships with several GOJEK drivers who seemed to be not open or not disclosed. Moreover, the groups formed by the GOJEK drivers, whether formed before or after the conflicts, have very strong solidarity ties. The communication that occurs is likely to run intensely as a form of resistance from the conflict. Conflict with conventional transportation drivers allows them to be more aware of the importance of alliances with other small groups that benefit their existence (Junio, 2017; $6 ; 1 ; 32)$.

According to Sourdin, conflict is very likely to occur in response to the entry of disruptive innovation. The online motorcycle taxi application can be called as disruptive innovation. This is because Go-Jek is a new technology investment that create easier motorcycle taxi with more affordable rates, which encourages people to switch using online motorcycle taxi services. As a result, the position of conventional motorcycle taxi as existing motorcycle taxi service providers has been shifted first. Conventional motorcycle taxi riders who feel their existence are threatened, finally take action against the existence of online motorcycle taxi which leads to conflicts with online motorcycle taxi riders from Go-Jek (Hasanah, 2019; Journal; 7: 2; 147).

Such conflicts are indeed difficult to avoid, because conventional motorcycle taxi riders who are already dependent on conventional systems feel the system is disturbed when faced with new technological innovations, which is online motorcycle taxis. Online motorcycle taxis are a form of technological advancement in the field of transportation, where previously people get motorcycle taxi services in conventional way, and now it becomes easier by using applications on smartphones. The conflict events include:

\subsubsection{Surakarta City is Inseparable from the Conflict between Online Motorcycle Taxi Riders and Conventional Motorcycle Taxi Riders. This Conflict can be Identified from the following Incidents:}

- Tuesday, October 11, 2016, an online motorcycle taxi rider (Go-Jek) named Kristian Wibowo (31 years old) took place at around 21.30 Western Indonesian Time at the Purwosari railway crossing, Surakarta was stopped by five people wearing orange vests who were 
suspected as conventional motorcycle taxi riders from Purwosari Station motorcycle taxi base, Solo.

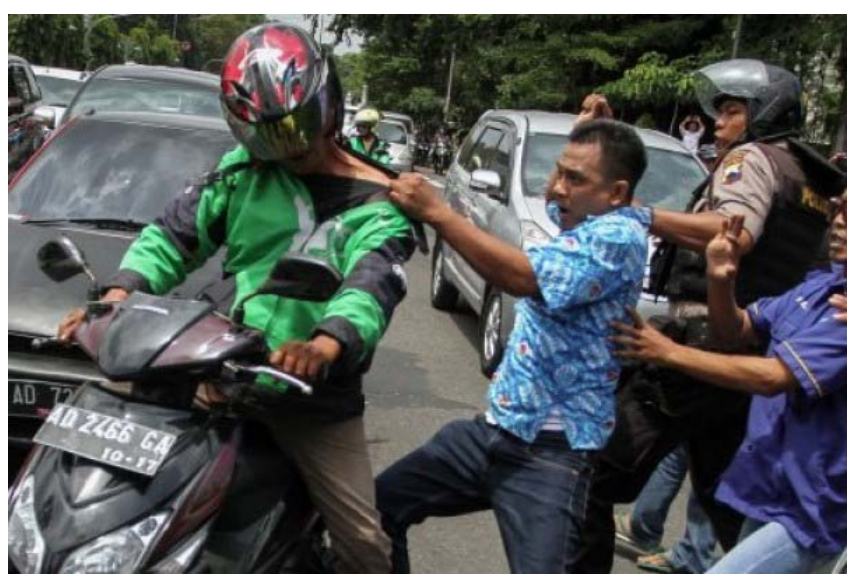

Figure 7: Physical Violent Conflict between GOJEK RIDER drivers and conventional OJEK drivers, in Solo, Surakarta, Central Java. Indonesia.

- Wednesday, 15 March 2017at around 11.00 Western Indonesia Time, a clash occurred in front of Solo City Hall between conventional motorcycle taxi riders and online motorcycle taxi riders (Go-Jek). Conventional motorcycle taxi riders who were taking part in the online motorcycle taxi rejection demo in yard of Solo City Hall saw online motorcycle taxi riders (GoJek) driving in groups in front of Solo City Hall, causing conventional motorcycle taxi riders to run to the road to stop the online motorcycle taxi riders, and then clash between the two parties occurred.

- Wednesday, May 152017 at around 9:15a.m. Western Indonesia Time, there was a conflict between online motorcycle taxi riders (Go-Jek) and conventional motorcycle taxi riders at Purwosari Station. The conflict occurred because online motorcycle taxi riders stood by across Purwosari Station so that conventional motorcycle taxi riders and other conventional transportation drivers tried to get rid of the online motorcycle taxi riders. The Surakarta Police could prevent this conflict by asking online motorcycle taxi riders to disperse (Hasanah, 2019; Journal; 7: 2; 147).

The process of conflict between online motorcycle taxi riders and conventional motorcycle taxi riders in Surakarta began with online motorcycle taxi riders who did not comply with the policies of Surakarta City Government by still taking passengers. At first, the presence of online motorcycle taxis in Surakarta has not received interest from the public, because the number of drivers is still small so that people rarely use their services. Then, the number of online motorcycle taxi riders was increasing, encouraging people who were previously conventional motorcycle taxi customers to switch using online motorcycle taxi services because the rates were cheaper and access to messages was easier. The large number of people who choose to use online motorcycle taxi services causes conventional motorcycle taxi passengers to decrease so that their income decreases. As a result, there is a feeling from conventional motorcycle taxi riders that their work area has been seized by online motorcycle taxi riders. This feeling eventually led the conventional motorcycle taxi riders to threat or do physical violence against online motorcycle taxi riders as a form of their rejection of the existence of online motorcycle taxis in Surakarta area (Hasanah, 2019; Journal; $7: 2 ; 154$ ).

\subsubsection{Bandar Lampung, Sumatra also cannot be Separated from the Conflict between Online Motorcycle Taxi Riders and Conventional Motorcycle Taxi Riders. The Conflict can be Identified from the following Incident}

- Conventional motorcycle taxi in collaboration with angkot drivers committed unlawful acts. At the beginning, they were looking for a trouble with online motorcycle taxi riders on Sebesi Island road, Sukarame Bandar Lampung and in the end, online motorcycle taxi riders defended their fellow rider, because his head was hit with a stone by a conventional motorcycle taxi rider emotionally. Online motorcycle taxi riders also took revenge by using knife on the road, then the victim's stomach was beaten who was an angkot driver, so that they were rushed to the hospital (Perdana, 2018; Thesis: 30)

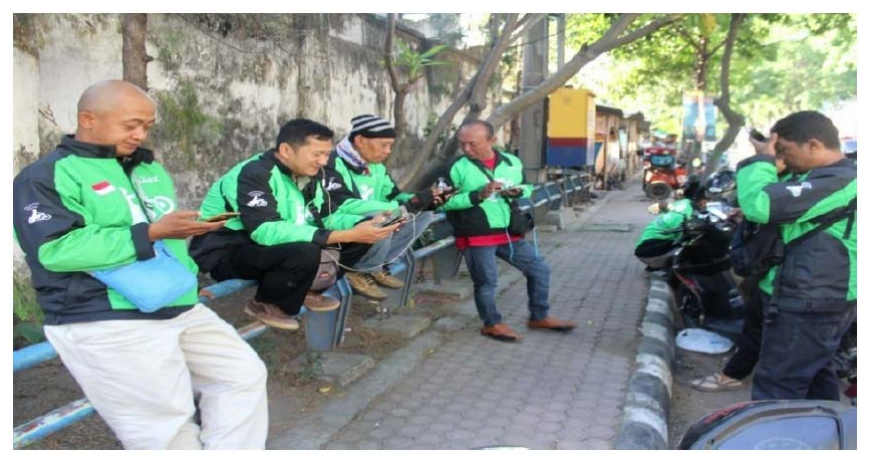

Figure 8: Physical Violent Conflict between GOJEK RIDER drivers and conventional OJEK drivers, in Bandar Lampung, Sumatra. 


\subsubsection{Kediri, East Java, is Inseparable from a Conflict between Online Motorcycle Taxi Riders and Conventional Motorcycle Taxi Riders. The Conflict can be Identified from the following Incident}

- $\quad$ According to the informant, he had experienced conflicts when picking up customers at the station. He picked up passenger in areas that was quite far from the station, but in fact the pedicab riders actually spread out at those far points. After determined the pick-up point, his motorcycle was thrown by stones even though it only tire was hit by. Those people did that by insulting and throwing the online-based motorcycle taxi rider (GOJEK) who was still picking up passengers at the station. After the incident, his GOJEK group was going around by taking consumers together. The informant also had a conflict with a driver of conventional motorcycle transportation (OJEK) or opang. He was chased by three conventional motorcycle taxi riders and finally he got off and showed that the tariff was only Rp.3,000. He offered to the three conventional motorcycle taxi riders and they refused. The conventional motorcycle taxi riders tend to be very sensitive even only when they open the cellphone. The positive thing about this conflict is that GOJEK knows better about certain points where they can go or not so that the conflicts don't occur again. What happens in the field is that the pick-up point is actually prohibited by conventional transportation, especially rickshaws rather than opang. Like it or not, GOJEK has to have a team that can provide backing on such conflicts (GOJEK forms certain groups, Junio, 2017 Journal of Sociological Analysis. Vol. 6 No.1:28).

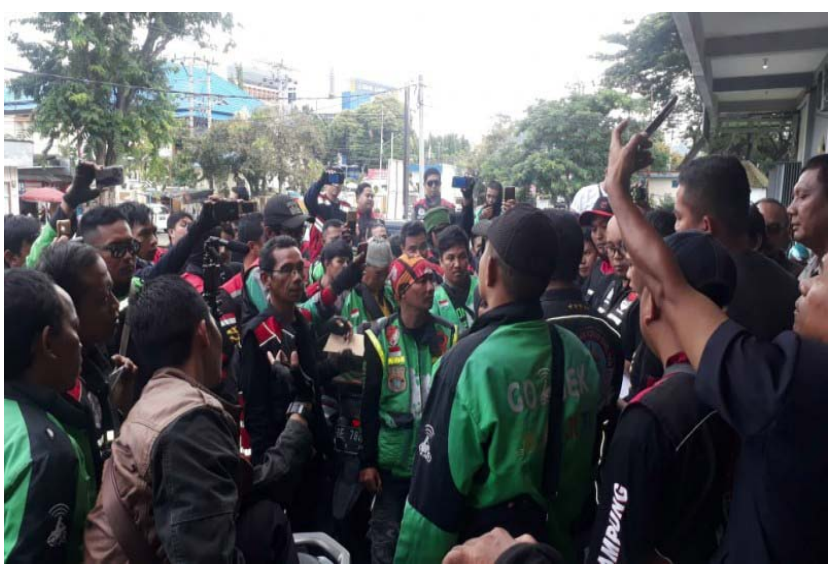

Figure 9: GO-JEK Drivers in Kediri City Avoid Conflict with Physical Violence with Conventional OJEK drivers.
3.3.4. Padang, West Sumatra is Inseparable from a Conflict between Online Motorcycle Taxi Riders and Conventional Motorcycle Taxi Riders. The Conflict can be Identified from the following Incident

- The conflict that occurred between online motorcycle taxi riders in Air Tawar Barat has resulted in the conflicting parties taking the initiative to strengthen the bonds of togetherness and kinship between them. According to the conflict theory, the strength of internal solidarity and group integration will become stronger because the level of conflict and conflict with opponents will be greater. The conflict between online motorcycle riders and conventional motorcycle taxi riders makes each of the conflicting parties gets stronger. The solidarity of one of the conflicting parties will stick out and get tighter because they feel distress and share the same interests, which is the struggle for areas to get orders in Air Tawar Barat, precisely in Cendrawasih. Each party unites to strengthen solidarity between them to be able to face conflicts together (Arbi, 2019: Journal of Sociological Studies; 2: 3: 321-322)

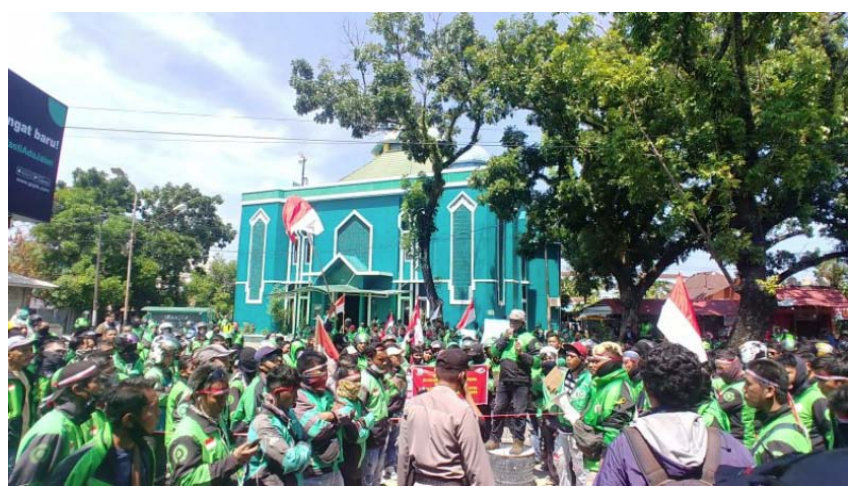

Figure 10: GOJEK ONLINE Driver Conflict with Conventional OJEK drivers because Conventional OJEK Revenues Decrease.

\subsubsection{Makassar, Ujung Pandang, South Sulawesi cannot be Separated from the Conflict between Online Transportation and Conventional Transportation Drivers. The Conflict can be Identified from the following Incidents}

- Online transportation raids conducted by conventional transportation drivers took place in front of the Makassar Governor's Office on November 1, 2017. This was the culmination of a protracted conflict because online transportation was considered to be operating illegally. Therefore, when they found a black plate car carrying passengers, the conventional 
transportation drivers forced the passengers to get off. As a result of this action, the passengers were stranded and had to walk. This action often ended in anarchism by destroying the vehicle. (Anwar 2017: Indonesian Journal of Ethnography: 2: 2: 234)

- Destruction of online transportation vehicles (GrabCar) was made by the conventional transportation drivers who demanded the closure of the application-based transportation. The security forces were unable to repel the demonstrators who committed the vandalism on November 1, 2017 in front of the Governor's Office. The strike action of hundreds of share taxi drivers (angkot) had occurred before on Sultan Alauddin Makassar street as a form of protest and rejection of online-based transportation. In addition, they also rejected the increase in administrative rates for vehicles operating in Makassar. In their action, conventional transportation drivers carried out strike and sweeping against online transportation operation. Apart from strikes and sweeping, the conventional angkot drivers also went to the Makassar Mayor's Office to respond to their requests (Anwar 2017: 2: 2:235). The UULLAJ No. 22/2009 does not regulate the use of Individual Motor Vehicles (black plate) because these vehicles are categorized as private property, and the state has no authority regarding the use or use of one's private property. But the state regulates everything that concerns the public interest

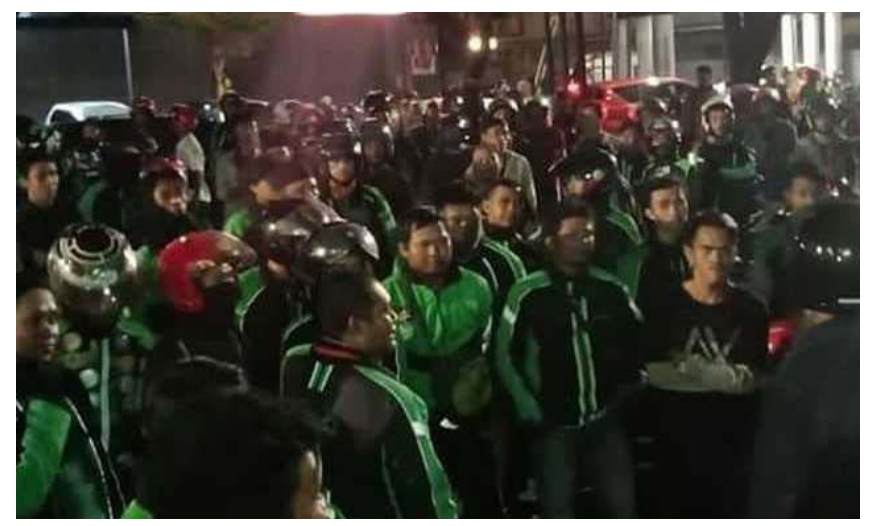

Figure 11: Conflict of GOJEK Drivers with Conventional OJEK drivers in Makassar City.

Based on the results of the research data, there was a social conflict between online and conventional land-based transportation drivers/riders due to the absence of legal online-based transportation regulations and legal certainty. Likewise, the factor of economic interest is related to competition in getting passengers, so that the source of income for conventional transportation drivers/riders is difficult to meet their living expenses.

\section{CONCLUSION}

Based on the research data above, it could be concluded that the inconsistencies of public policy regulations in land transportation of motorcycles (twowheeled vehicles), as online-based public transportation vehicles based on PM 12/2019 in article 3 paragraph (2) community as referred to in paragraph (1) must fulfill the following aspects: a. safety; b. security; c. comfort; d. affordability; and e. regularity. Article 7 paragraph (1) on the fulfillment of the affordability aspect as referred to in Article 3 paragraph (2) letter $d$ must at least fulfill the following conditions: a. The driver/rider provides services to the Passenger to the destination point according to the agreement between the Driver/Rider and Passenger; and $b$. The driver/rider charges a service fee according to the agreement between the driver/rider and passenger. In UULLAJ/2009. Article 47 paragraph (2),motor vehicles as referred to in paragraph (1) letter a are categorized by type: a. motorcycle; b. passenger car; c. bus; d. freight wagon; and e. special vehicle. Article 47 paragraph (3) on Motor Vehicles as referred to in Article 47 paragraph (2) letter b, letter c, and letter d are categorized by function as follows: a. Individual motor vehicles; and b. Public Motor Vehicles. In this case, motorcycles are not included in the category of public transportation types.

The immediate solution should be made based on the results of research on online-based land transportation to date in Indonesia, since it has not been regulated by regulations on public transportation. Moreover, the technology platform service providers can no longer deny that their services are actually public transportation services. Online-based land transportation must also be regulated in the form of laws and regulations on public transportation and under the law on road traffic and transportation. This indicates that Law Number 22 of 2009 on Road Traffic and Transportation needs to be revised, and at the same time should provide a legal protection for the regulations related to online-based land transportation.

\section{REFERENCES}

Anwar Amalia Ahsani (2017) Online vs Konvensional: Keunggulan dan Konflik Antar Moda Transportasi di Kota Makassar, Jurnal Etnografi Indonesia Vol. 2 Edisi 2.

https://doi.org/10.31947/etnosia.v2i2.3012 
Apriani Fajar (2019) Konflik Antar Nilai bagi Suksesi Perubahan Kebijakan dalam Pengembangan Organisasi, Jurnal Analisis Kebijakan dan Pelayanan Publik, Juni, Vol 5 No.1, page 6279.

https://doi.org/10.31947/jakpp.v1i1.7791

Arbi Ramadhan Fazlaura dan Susilawati Nora (2019) Konsekuensi yang Muncul Setelah Terjadinya Konflik Antara Ojek Online dengan Ojek Konvensional di Air Tawar Barat, PadangJurnal Perspektif: Jurnal Kajian Sosiologi dan Pendidikan Vol. 2 No.3.

https://doi.org/10.24036/perspektif.v2i3.107

Ariesandi Ayu Junita, Resita Reiza, dan Salsabila Zulfitri (2020) Kebijakan Transportasi Umum Untuk Menanggulangi Kemacetan Jalan, Jurnal Kebijakan Publik, Volume 11, Nomor 2,Oktober hlm. 55-112 https://doi.org/10.31258/jkp.11.2.p.77-82

Baswedan Anies,( 2020) virus corona: PSBB dan ojek bawa penumpang: Simpang siur yang meningkatkan risiko Covid19. BBC News Indonesia. https://www.bbc.com/indonesia/indonesia-52271905

Hasanah Nurul, Triyanto, Rusnaini, (2019) Anatomi Konflik Antara Pengemudi Ojek Online dengan Ojek Konvensial di Kota Surakarta. Jurnal PPKn. Juli. Vol.7 No, 2, page 44-160

Indonesia Republik Undang-Undang Nomor 22 Tahun 2009 Tentang Lalu Lintas dan Angkutan Jalan.

Junio Swastika Mega (2017) Fungsionalitas Konflik Gojek: Studi Fenomenologi Terhadap Konflik Pengemudi Gojek di Kota Kediri, Jurnal Analisa Sosiologi. Vol. 6 No. 1. P 16-32

Monoarfa Nurhayati (2020) Revisi UU Lalu Lintas, Dewan Perwakilan Rakyat Republik Indonesia Tolak Motor Roda Dua Jadi Angkutan Umum, CNN Indonesia | Rabu, 19/02/2020 16:34 WIB.https://www.cnnindonesia.com/nasional/2020021916005532-476147/revisi-uu-lalu-lintas-dpr-tolak-motor-jadi-angkutanumum/

Mutiarin Dyah, Nurmandi Achmad, Jovita Hazel, Fajar Mukti and Lien Nan-Yao (2019) How do government regulations and policies respond to the growing online- enabled transportation service (OETS) in Indonesia, the Philippines, and Taiwan? Digital Policy, Regulation and Governance. https://doi.org/10.1108/DPRG-01-2019-0001

Ouadi El Jihane, Malhene Nicolas, Benhadou Siham and Medromi Hicham (2020), Strategic zoning approach for urban areas: towards a shared transportation system, Procedia Computer Science Vol.170. Page 211-218 https://doi.org/10.1016/j.procs.2020.03.027

Peraturan Menteri Kementerian Perhubungan Republik Indonesia Nomor PM 12 Tahun 2019 Tentang Perlindungan dan Keselamatan Pengguna Sepeda Motor Yang Digunakan Kepentingan Masyrakat.

Perdana Agung Muhammad (2018) Faktor Penyebab Konflik Antara Ojek Online dan Ojek Konvensional (Studi Kasus Ojek Online dan Konvensiona di Kota Bandar Lampung), Skripsi.
Fakultas IImu Sosial dan IImu Politik Universitas Lampung, Bandar Lampung, Indonesia

Prihatin Budi Rohani(2017)KonflikSosialTransportasi Konvensional Versus Transportasi Berbasis Online. Majalah Info Singkat Kesejahteraan Sosial. Pusat Penelitian Badan Keahlian Dewan Perwakilan Rakyat Republik Indonesia. Vol 9 No.7

Riyadi Slamet Bambang, Hermanto Bambang Asep, Harlina Indah, Purnomo Hadi (2020) Discretion of Power of the Indonesian National Police Impacts the Abuse of Power in the Case of Letter Forgery of Red Notice "Fugitive Djoko Tjandra. International Journal of Criminology and Sociology. Vol 9. Page1292-1300 https://doi.org/10.6000/1929-4409.2020.09.148

Riyadi Slamet Bambang (2017) The Philosophy of Law Review; According to Pancasila Ideology Value in Agrarian Disputes Upon The Egendom Verponding Land. International Journal of Development Research Vol. 07, June, Issue, 06, pp.13011-13018

Riyadi Slamet Bambang (2017) Sociology of law: An agrarian dispute settlement, International Journal of Law ISSN: 24552194,RJIF 5.12 www.lawjournals.org Volume 3; Issue 3;May; Page No. 52-58

Riyadi Slamet Bambang (2020) Culture of Abuse of Power in Indonesia from the Perspective of Criminology and Law, International Journal of Criminology and Sociology, Vol.9, page $274-284$

Rofiqi Hasbi Moh. (2020) Politik Kebijakan Pemerintah Presiden Joko Widodo Terhadap Trasnportasi Berbasis Online Tahun 20142019, Journal of Politics and Democracy Studies, Universitas Indonesia.

Setijowarno Djoko (2020) virus corona: PSBB dan ojek bawa penumpang: Simpang siur yang meningkatkan risiko Covid19. Masyarakat Transportasi Indonesia, Ketua Advokasi Dan Kemasyarakatan Organisasi, BBC News Indonesia. https://www.bbc.com/indonesia/indonesia-52271905

Siregar Efrem (2019) UU Akan Diubah, Ojek Diusulkan Jadi Transportasi Resmi CNBC Indonesia02 November 2019 21:02 https://www.cnbcindonesia.com/news/20191102205616-4112229/uu-akan-diubah-ojek-diusulkan-jadi-transportasiresmi

Soekanto, Soerjono. (2009). Peranan Sosiologi Suatu Pengantar. Rajawali Press. Jakarta

Sutopo HB. (2002). Metodologi Penelitian Kualitatif.Surakarta: UNS Press.

Yogo Purnomo Sambodo, (2020) virus corona: PSBB dan ojek bawa penumpang: Simpang siur yang meningkatkan risiko Covid19. BBC News Indonesia. https://www.bbc.com/indonesia/indonesia-52271905

Yuniar Woro Resty (2020) virus corona: PSBB dan ojek bawa penumpang: Simpang siur yang meningkatkan risiko Covid19. BBC News Indonesia. https://www.bbc.com/indonesia/indonesia-52271905

\section{https://doi.org/10.6000/1929-4409.2021.10.87}

(C) 2021 Gusti et al.; Licensee Lifescience Global.

This is an open access article licensed under the terms of the Creative Commons Attribution Non-Commercial License (http://creativecommons.org/licenses/by-nc/3.0/) which permits unrestricted, non-commercial use, distribution and reproduction in any medium, provided the work is properly cited. 